\title{
Organs of BALB/c mice can be injured in course of tularemia
}

\author{
Oto Pavlis ${ }^{\mathrm{a}, \mathrm{b}}$, Eva Kusakovac, Ladislav Novotny ${ }^{\mathrm{b}}$, Miroslav Pohanka ${ }^{\mathrm{b}, \mathrm{d}}$
}

Background. Francisella tularensis is a biological agent exploitable for bioterrorism and biological warfare purposes due to serious pathogenic progression and easy dissemination. Despite intensive research in the past, some adverse consequences remain unclear. One consequence of this pathogen is oxidative stress.

Aims. The aim of this study was to undertake ex vivo assays for monitoring the disease in mice and increase our knowledge of the oxidative stress induced by tularemia.

Methods. The mouse BALB/c model was chosen and the animals were infected by a dose $10^{4} \mathrm{CFU}$ of $F$. tularensis. After five days, the animals were euthanized. Blood immediately processed in plasma, spleen and liver were sampled from the cadavers. Oxidative stress markers, cytokines and histopathological were undertaken.

Results. There was a significant link between oxidative stress and tularemia. Particularly elevated levels of malondialdehyde and decreased levels of low molecular weight antioxidants were found in the liver and spleen of tularemia-infected animals. The histopathological findings correlated well with the oxidative stress markers. The liver and spleen were proven to be significantly at risk from the disease and an association between stress and neutrophils in the affected organs was found. The histopathology excluded risk to other organs such as the kidney and or heart.

Conclusions. Oxidative stress plays a significant role in tularemia infection in mice and this was confirmed by the histology.

Key words: Francisella tularensis, intracellular pathogen, liver, spleen, reactive oxygen species, antioxidants

Received: September 7, 2012; Accepted with revision: January 17, 2013; Available online: March 22, 2013

http://dx.doi.org/10.5507/bp.2013.006

${ }^{a}$ Centre of Biological Defense, 56166 Techonin, Czech Republic

${ }^{b}$ Faculty of Military Health Sciences, University of Defense, Trebesska 1575, 50001 Hradec Kralove

'Department of Biological and Biochemical sciences, Faculty of Chemical Technology, University of Pardubice, Studentska 573, 532 10

Pardubice

${ }^{d}$ Central European Institute of Technology, University of Technology in Brno, Technicka 3058/10, 61600 Brno

Corresponding author: Miroslav Pohanka, e-mail: miroslav.pohanka@gmail.com

\section{INTRODUCTION}

Francisella tularensis is a potential biological warfare agent causing the infectious disease, tularemia. This has several manifestations based on route of entry of the pathogen.

Tularemia, also known as rabbit-fever or deer-fly fever, is caused by the gram-negative intracellular pathogen $F$. tularensis (ref. ${ }^{1,2}$ ). The pathogen is categorized into four subspecies, F. tularensis subsp. tularensis (called Type A) and $F$. tularensis subsp. holarctica (called Type B) which is recognized as the principal causes of human tularemia ${ }^{3-6}$. The A type is the most virulent subspecies and it is associated with illness in North America, Canada,and Mexico among others. The B type is less virulent and responsible for almost all tularemia infections in Europe ${ }^{7,8}$. where it does not usually cause human mortality. The third subspecie is virulent $F$. tularensis subsp. mediasiatica and has been isolated in central Asia. The last, F. tularensis subsp. novicida is generally avirulent in humans, and has been reported in Australia ${ }^{9}$.

F. tularensis is typically found in small mammal species and the most important vectors are rabbits, hares, mice and rodents ${ }^{6,10,11}$. Humans become infected in several ways, including direct contact with infected dead or live animals or their products, ingesting contaminated food or water, and inhaling contaminated aerosols ${ }^{12,13}$. The most common mode of transmission is from blood-sucking arthropods, by ticks, deer flies and mosquitoes. The transmission of $F$. tularensis person-to-person (secondary transmission) is usually considered improbable. The infective dose can be as low as 10 bacterial cells ${ }^{3,14,15}$.

Tularemia caused by $F$. tularensis has a wide variety of clinical manifestations. This generally depends on the route of entry ${ }^{12,16}$. The most common clinical forms are ulceroglandular (infection through the skin) and respiratory (infection by inhalation) (ref. ${ }^{9,17}$ ). Other forms of the disease are oculoglandular, oropharyngeal, gastrointestinal and typhoidal tularemia ${ }^{12,13,18}$.

Tularemia is reported primarily in the Northern Hemisphere. Endemic foci of tularemia are found in North America, Europe, Asia, and occasionally in Africa ${ }^{19}$. In particular, tularemia cases in Europe are mainly concentrated in Germany, Sweden, British Columbia, Norway and France ${ }^{4,20,21}$. Other cases are reported in Japan, Alaska, Sudan and Turkey ${ }^{22-24}$. Currently, outbreaks caused by $F$. tularensis are generally rare and sporadic as the spread and incidence of the disease has been steadily decreasing ${ }^{25}$. 
Though the pathogenesis of tularemia has been extensively investigated ${ }^{26}$ and its role in oxidative stress was proven in disparate infectious diseases ${ }^{27}$, the effect of tularemia on oxidative homeostasis and oxidative stress initiation remains unclear ${ }^{28}$. The present experiment was focused on investigation of oxidative stress and antioxidants levels in laboratory animals infected with tularemia. We hypothesized that tularemia can induce oxidative imbalance in the most endangered organs.

\section{MATHERIAL AND METHODS}

\section{Bacterium}

F. tularensis LVS (ATCC 29684) was cultivated on McLeod agar supplemented with bovine haemoglobin and Iso VitaleX (Becton-Dickinson, San Jose, CA, USA) as described previously ${ }^{29}$. After two days, cells were harvested and washed in saline solution with centrifugation $2,000 \times \mathrm{g}$ for $10 \mathrm{~min}$. The concentration of fresh cells was estimated using a cell density meter (WPA, Cambridge, UK) and confirmed by a cultivation test.

\section{Animals and tissues processing}

In a total, 20 female three month old $\mathrm{BALB} / \mathrm{c}$ mice (BioTest, Konarovice, Czech Republic) weighing $20 \pm 2$ $\mathrm{g}$ were divided into two groups. The mice were kept in a stable temperature $(22 \pm 2 \mathrm{C})$ and humidity $(50 \pm 10 \%)$. They had a constant source of light from 7 a.m to 7 p.m and free access to water and chow. The experiment was carried out at the vivarium of the Centre of Biological Defense in Techonin (Czech Republic) and permitted by central ethics commission (Ministry of Defense, Czech Republic). F. tularensis was suspended in saline up to a concentration of $10^{5} \mathrm{CFU} / \mathrm{mL}$. $100 \mu \mathrm{L}$ of $F$. tularensis suspension was applied to the first ten mice. The last ten animals received $100 \mu \mathrm{L}$ of saline solution (controls animals). The experiment ended five days later when the animals were sacrificed in $\mathrm{CO}_{2}$ anaesthesia by heart punction. The spleens and livers were collected immediately. Each $100 \mathrm{mg}$ of organ tissue was placed in $1 \mathrm{~mL}$ of phosphate buffered saline and homogenized by mixing at 8,000 rotations per min for $1 \mathrm{~min}$ using Ultra-Turrax (Ika Werke, Staufen, Germany). Blood was collected into heparinised tubes by cutting the jugular vein and the plasma was taken after centrifugation at $3,000 \times \mathrm{g}$ for $15 \mathrm{~min}$.

\section{Ex vivo assays}

Thiobarbituric acid reactive substances (TBARS), ferric reducing antioxidant power (FRAP), reduced glutathione (GSH) and glutathione reductase (GR) were assayed in compliance with the previously optimized protocols in the spleen and liver ${ }^{30-32}$. For the TBARS assay, $67 \mathrm{mg}$ of thiobarbituric acid (Sigma-Aldrich) was dissolved in $1 \mathrm{ml}$ dimethylsulfoxide prior to solving in $9 \mathrm{~mL}$ of deionized water. Separately, $100 \mu \mathrm{L}$ of tissue homogenate was treated with $200 \mu \mathrm{L}$ of $10 \%$ trichloroacetic acid for $15 \mathrm{~min}$ on ice. After centrifugation at $3000 \times \mathrm{g}$ for $15 \mathrm{~min}, 200 \mu \mathrm{L}$ of supernatant (or equivalent amount of saline solution as blank) was poured into a thermostable plastic tube, mixed with $200 \mu \mathrm{L}$ of thiobarbituric acid solution and heated at $100{ }^{\circ} \mathrm{C}$ for $10 \mathrm{~min}$. Absorbance was measured at 532 nm shortly after the mixture had cooled. The value of the TBARS (molar scale) was calculated using the extinction coefficient $\varepsilon=156,000 \mathrm{M}^{-1} \mathrm{~cm}^{-1}$.

Low molecular weight antioxidants were assayed as the ferric reducing antioxidant power (FRAP). $2.5 \mathrm{~mL}$ of $10 \mathrm{mM}$ 2,4,6-tris(2pyridyl)-s-triazine in $40 \mathrm{mM} \mathrm{HCl}$ were poured together with $2.5 \mathrm{~mL} 20 \mathrm{mM} \mathrm{FeCl}_{3}$. The mixture was dissolved in $25 \mathrm{~mL}$ of $0.1 \mathrm{M}$ acetate buffer pH 3.6 and warmed at $37{ }^{\circ} \mathrm{C}$ for $10 \mathrm{~min} .200 \mu \mathrm{L}$ of fresh 2,4,6-tris(2pyridyl)-s-triazine solution were mixed with $30 \mu \mathrm{L}$ of tissue homogenate (saline solution as blank) and $1 \mathrm{~mL}$ of deionized water. After $10 \mathrm{~min}$ incubation, the mixture was spun at $10,000 \times g$ for $10 \mathrm{~min}$. Supernatant absorbance was measured at $593 \mathrm{~nm}$. The extinction coefficient $\varepsilon=26,000 \mathrm{M}^{-1} \mathrm{~cm}^{-1}$ was used to calculate the FRAP molar value.

The assay of GR: disposable PS cuvette was filled with $100 \mu \mathrm{L}$ of $10 \mathrm{mM}$ oxidized glutathione (GSSG; SigmaAldrich) and the same volume of $1 \mathrm{mM}$ NADPH (SigmaAldrich). $650 \mu \mathrm{L}$ of PBS and $100 \mu \mathrm{L}$ of $10 \mathrm{mM}$ EDTA diluted the suspension. The kinetics assay was started by addition of $50 \mu \mathrm{L}$ tissue homogenate. Consumption of NADPH was assayed in a two minute interval and the enzyme activity was calculated from the absorbance change and extinction coefficient $\varepsilon=6,220 \mathrm{M}^{-1} \mathrm{~cm}^{-1}$.

The assay of GSH: $100 \mu \mathrm{L}$ of homogenate was to remove proteins using $2.5 \%(\mathrm{v} / \mathrm{v})$ trichloroacetic acid $(600 \mu \mathrm{L})$ and spun at $12,000 \times \mathrm{g}$ for $5 \mathrm{~min}$. After centrifugation, $500 \mu \mathrm{L}$ of the fresh supernatant was neutralized with $125 \mu \mathrm{L}$ of $0.5 \mathrm{M}$ sodium hydroxide. $400 \mu \mathrm{L}$ of the precipitated and neutralized sample was mixed with 400 $\mu \mathrm{L}$ of $5,5^{\prime}$-dithiobis-2-nitrobenzoic acid $(0.4 \mathrm{mg} / \mathrm{mL})$ and absorbance was measured at $412 \mathrm{~nm}$. Level of GSH was calculated using extinction coefficient $\varepsilon=14,150 \mathrm{M}^{-1} \mathrm{~cm}^{-1}$.

Interferon gamma (IFN- $\gamma$ ) assay: IFN- $\gamma$ level in plasma was measured using a Mouse IFN- $\gamma$ Eli-pair kit (Abcam, Cambridge, MA, USA) as recommended by the manufacturer. Pure IFN- $\gamma$ was used for the calibration.

\section{Histopathology}

Samples of liver, kidney, lung, spleen, heart and skin from the site of application were collected into $10 \%$ buffered formalin and processes using a standard paraffin histological technique. The samples were then stained by haematoxylin and eosin. The slides were inspected by optical microscopy with a digital output (Olympus BX 35; Olympus; Japan).

\section{Statistical analysis}

Origin 8 (OriginLab Corporation, Northampton, MA, USA) was used for data processing. The significance of differences between groups was estimated using one-way analysis of variance with Tukey test. The significance was recalculated for two probabilities levels $P=0.05$ for the group size $n=10$. 


\section{RESULTS AND DISCUSSIONS}

The FRAP value was assayed in both spleen and liver (Table 1). Against the controls, the FRAP was not significantly shifted in the animals ' livers in the course of tularemia. In the spleen the FRAP level was reduced in the animals infected with tularemia. We can infer partial depletion of antioxidants resulting in higher vulnerability to oxidative stress as described further. We found a good example of induced oxidative imbalance in the selected organs. As a second assay for antioxidants, we chose assessment of GSH in the examined organ. The results are summarized in Table 2. The level of GSH was significantly reduced in both spleen and liver. The findings are not surprising as depletion of antioxidants can play a role in the disease progression ${ }^{33}$. Moreover, GSH is required by $F$. tularensis for its metabolism. Hence the level can be easily depleted ${ }^{34}$.

GR was evaluated in tissues samples. The found enzyme activities per kilogram of tissue are shown in Table 3 . The liver GR was relatively steady and we found no shifts in its activity indicating that GR probably does not play any extensive role in oxidative stress induced by tularemia. The proven steady level of GR confirms the above mentioned hypothesis that GSH is acquired by $F$. tularensis. The enzyme activity increases with increased level of GSSG $\left(\right.$ ref. $\left.^{35}\right)$. The finding can be interpreted that GSH is consumed by metabolism rather than oxidized to GSSG. Direct proof is, however, missing. The found shifts in TBARS level are depicted in Table 4. Both liver and spleen had increased content of malondialdehyde indicating development of oxidative stress. We can use the method for monitoring of stress state with very good results. From a literature search, $F$. tularensis is quite resistant to oxidative stress and it can recovery from stress conditions more easily than the host organism ${ }^{36}$.

IFN- was assessed in plasma samples (Table 5). In accord with expectation, the level was significantly increased in the course of tularemia. IFN- is a cytokine necessary for comabting the disease. Macrophages are more effective in killubg the intracellular pathogen when they are co-stimulated by the IFN- $\gamma\left(\right.$ ref. $\left.^{37,38}\right)$. Here, we used IFN- $\gamma$ as a marker of the progress of the infection. The controls had minimal levels of IFN- $\gamma$. The level was near the limit of detection for the ELISA method. The infected mice had significantly increased IFN- $\gamma$ level which indicates successful combat of the disease.

The histopathological examination showed significant damage to the tested organs following the tularemia infection. The hallmark of tissue change was pyogranulomatous inflammation. The most pronounced changes were seen in the skin and subcutaneous tissue in the infected animals. Moderate and severe necrosis was also observed in the liver (see Fig. 1) in all animals infected with tularemia. Focal accumulation of neutrophils was found in the spleen together with activation of germinative centers and hyperplasia of white pulp. There were no morphological changes in other tissues (kidney, heart, lungs and brain). The overall impact on tissues is summarized in Table 6 .
Table 1. Ferric reducing antioxidant power (FRAP) in examined organs.

\begin{tabular}{ccc}
\hline & Tularemia & Control \\
\hline Liver & $259 \pm 48(-)$ & $258 \pm 24$ \\
Spleen & $233 \pm 21(*)$ & $266 \pm 36$ \\
\hline
\end{tabular}

value in $\mu \mathrm{mol} / \mathrm{kg}$ : mean \pm standard deviation

* - probability level at 0.05

Table 2. Reduced glutathione (GSH) level.

\begin{tabular}{ccc}
\hline & Tularemia & Control \\
\hline Liver & $31 \pm 9(*)$ & $51 \pm 11$ \\
Spleen & $39 \pm 12\left({ }^{*}\right)$ & $57 \pm 14$ \\
\hline
\end{tabular}

value in $\mu \mathrm{mol} / \mathrm{kg}$ : mean \pm standard deviation

* - probability level at 0.05

Table 3. Glutathione reductase (GR) activity.

\begin{tabular}{ccc}
\hline & Tularemia & Control \\
\hline Liver & $6.36 \pm 2.42$ & $6.73 \pm 1.16$ \\
Spleen & $9.04 \pm 3.14$ & $8.34 \pm 1.13$ \\
\hline
\end{tabular}

value in $\mu \mathrm{kat} / \mathrm{kg}$ : mean \pm standard deviation

Table 4. Thiobarbituric acid reactive substances (TBARS) activity.

\begin{tabular}{ccc}
\hline & Tularemia & Control \\
\hline Liver & $167 \pm 20\left(^{*}\right)$ & $135 \pm 26$ \\
Spleen & $150 \pm 19(*)$ & $115 \pm 9$ \\
\hline
\end{tabular}

value in $\mu \mathrm{mol} / \mathrm{kg}$ : mean \pm standard deviation

* - probability level at 0.05

Table 5. Interferon gamma (IFN- $\gamma$ ) assay in plasma samples.

\begin{tabular}{ccc}
\hline IFN- $\gamma$ & Tularemia & Control \\
\cline { 2 - 3 }$(\mathrm{pg} / \mathrm{mL})$ & $755 \pm 71(*)$ & $15 \pm 13$ \\
\hline
\end{tabular}

value in $\mathrm{pg} / \mathrm{mL}$ : mean \pm standard deviation

* - probability level at 0.05

The histopathological examination confirmed our hypthesis that the spleen and liver are the most endangered organs during the disease. The presence and activation of neutrophils can cause the generation of reactive oxygen species as the cells are their significant source ${ }^{39}$.

The proven alterations in oxidative stress markers correspond well with our previous experiment on $\mathrm{BALB} / \mathrm{c}$ mice $^{40}$. In comparison with the quoted paper, we chose a ten fold lower dose of the pathogen in order to prevent serious nonspecific reactions in the body. The oxidative stress marker findings presented here and in the quoted 
Table 6. Histopathology examination.

\begin{tabular}{lll}
\hline Group & Tularemia & Controls \\
\hline Skin and subcutis & pyogranulomatous panniculitis and dermatitis +++ & normal morphology \\
Liver & liver necrosis, multiple focal and confluent & normal morphology \\
Spleen & focal infiltration with neutrophils, reactive hyperplasia of white pulp & normal morphology \\
Lungs & normal morphology & normal morphology \\
Heart & normal morphology & normal morphology \\
Kideny & normal morphology & normal morphology \\
Brain & normal morphology & normal morphology \\
\hline
\end{tabular}

paper point to oxidative injury in the examined organs and provide opportunity for introducing treatment based on oxidative stress reduction. In contrast to the previous work, we chose histopathological of the tested organs and role of neutrophils can be rationalized. Apart from the other animal models, the findings are in compliance with clinical findings on patients infected with tularemia ${ }^{41}$.

\section{CONCLUSIONS}

This study provides data from ex vivo assays for monitoring oxidative stress induced by tularemia in experimental animals. The FRAP method provided fair results for the kidney samples. The GR assay however was not as useful. TBARS is applicable for indicating the development of oxidative stress. We infer that oxidative stress plays a significant role in disease pathogenesis. However, it is not easy to judge whether the stress is a cause or a consequence of tularemia induced pathogenicity.

\section{ACKNOWLEDGEMENT}

A long-term organization development plan 1011 (Faculty of Military Health Sciences, University of Defence, Czech Republic) is gratefully acknowledged.

Authorship contributions: MP: literature search; OP, EK, MP: manuscript writing; OP, MP: study design; OP, EK, LN: data collection; OP, EK, LN: data analysis; OP, MP: data interpretation; OP, MP: statistical analysis, figures; MP: final approval.

Conflict of interest statement: The authors stated that there are no conflicts of interest regarding the publication of this article.

\section{REFERENCES}

1. Byström M, Böcher S, Magnusson A, Prag J, Johansson A. Tularemia in Denmark: Identification of a Francisella tularensis subsp.holarctica Strain by Real-Time PCR and High-Resolution Typing by MultipleLocus Variable-Number Tandem Repeat Analysis. J Clin Microbiol 2005;43(10):5355-8.

2. Gyuranecz M, Birdsell DN, Splettstoesser W, Seibold E, BeckstromSternberg SM, Makrai L, Fodor L, Fabbi M, Vicari N, Johansson

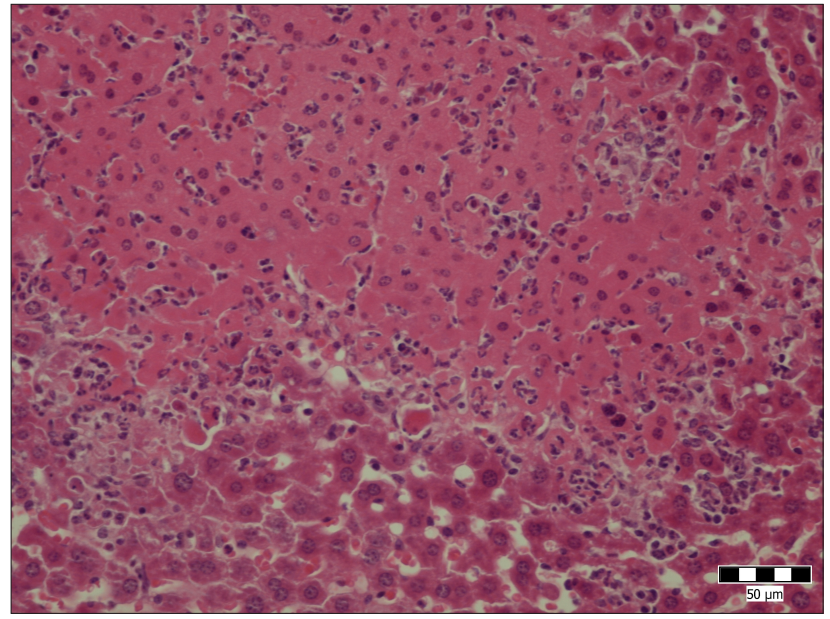

Fig. 1. Histological section of liver in mice infected with tularemia. There is marked necrosis moderately infiltrated with neutrophils. Haematoxylin and eosin staining.

A, Busch JD, Vogler AJ, Keim P, Wagner DM, 2012. Phylogeography of Francisella tularensis subsp. holarctica, Europe. Emerg Infect Dis 2012;18(2):290-3.

3. Dennis DT, Inglesby TV, Henderson DA, Bartlett JG, Ascher MS, Eitzen E, Fine AD, Friedlander AM, Hauer J, Layton M, Lillibridge SR, McDade JE, Osterholm MT, O'Toole T, Parker G, Perl TM, Russell PK, Tonat K. Tularemia as a biological weapon: medical and public health management. JAMA 2001;285:2763-73.

4. Mahy S, Chavanet P, Piroth L, Roch N, Duong M, Pelloux I, Maurin M. Emergence of tularemia in France: paradigm of the Burgundy region Int J Infect Dis 2011;15(12):882-3.

5. Marinov KT, Georgieva ED, Ivanov IN, Kantardjiev TV. Characterization and genotyping of strains of Francisella tularensis isolated in Bulgaria. J Med Microbiol 2009;58:82-5.

6. Nakazawa Y, Williams RA, Peterson AT, Mead PS, Kugeler KJ, Petersen JM. Ecological Niche Modeling of Francisella tularensis Subspecies and Clades in the United States. Am J Trop Med Hyg 2010;82(5):9128 .

7. Nigrovic LE, Wingerter SL. Tularemia. Infect Dis Clin North Am 2008;22(3):489-504.

8. Sjostedt A. Tularemia: history, epidemiology, pathogen physiology, and clinical manifestations. Ann NY Acad Sci 2007;1 105:1-29.

9. Nübel U, Reissbrodt R, Weller A, Grunow R, Porsch-Ozcurumez M, Tomaso H, Hofer E, Splettstoesser W, Finke E-J, Tschäpe H, Witte W. Population Structure of Francisella tularensis. J. Bacteriol 2006;14:5319-24.

10. Eliasson $\mathrm{H}$, Back E.Tularaemia in an emergent area in Sweden: an analysis of 234 cases in fi ve years. Scand J Infect Dis 2007;39:880-9.

11. Kugeler KJ, Mead PS, Janusz AM, Staples JE, Kubota KA, Chalcraft LG, Petersen JM. Molecular epidemiology of Francisella tularensis in the United States. Clin Infect Dis 2009;48:863-70. 
12. Foley JE, Nieto NC. Tularemia. Vet Microbiol 2010;140:332-8.

13. Santic M, Al-Khodor S, Abu Kwaik Y. Cell biology and molecular ecology of Francisella tularensis. Cell Microbiol 2010;12:129-39.

14. Keim P, Johansson A, Wagner DM. Molecular epidemiology, evolution, and ecology of Francisella. Ann NY Acad Sci 2007;1 105:30-66.

15. Rotz LD, Khan AS, Lillibridge SR, Ostroff SM, Hughes JM. Public health assessment of potential biological terrorism agents. Emerg Infect Dis 2002;8:225-30.

16. Eliasson H, Broman T, Forsman M, Back MD. Tularemia: current epidemiology and disease management. Infect Dis Clin North Am 2006;20:289-311.

17. Tarnvik A, Berglund L. Tularemia. Eur Respir J 2003;21:361-73.

18. Pilo P, Johansson A, Frey J. Identification of Francisella tularensis Cluster in Central and Western Europe, Emerg Infect Dis 2009;15(12):2049-51.

19. Oyston P, Quarry JE. Tularemia vaccine: past, present and future. Antonie van Leeuwenhoek 2005;87:277-81.

20. Isaac-Renton M, Morshed M, Mak S, Loyola V, Hoang L. Tularemia in British Columbia: A case report and review. BCMJ 2010;52(6):303-7.

21. Kaysser P, Seibold E, Matz-Rensing K, Pfeffer M, Essbauer S, Splettstoesser WD. Re-emergence of tularemia in Germany: presence of Francisella tularensis in different rodent species in endemic areas. BMC Infect Dis 2008;8:e157.

22. Hansen CM, Vogler AJ, Keim P, Wagner DM and Hueffer K. Tularemia in Alaska, 1938 - 2010. Acta Vet Scand 2011;18:53-61.

23. Mohamed SE, Mubarak Al, Alfarooq LO. Francisella tularensis Bacteremia: A Case Report from Sudan. Case Rep Infect Dis 2012:e405737.

24. Triebenbach AN, VogI SJ, Lotspeich-Cole L, Sikes DS, Happ, GM, Hueffer K. Detection of Francisella tularensis in Alaskan mosquitoes (Diptera: Culicidae) and assessment of a laboratory model for transmission. J Med Entomol 2010;47:639-48.

25. Tärnvik A, Chu MC. New approaches to diagnosis and therapy of tularemia. Ann NY Acad Sci 2007:1105:378-404.

26. Hepburn MJ, Simpson AJ. Tularemia: current diagnosis and treatment options. Expert Rev Anti Infect Ther 2008;6:231-240.

27. Cabiscol E, Tamarit J, Ros J. Oxidative stress in bacteria and protein damage by reactive oxygen species. Internat Microbiol 2000;3:3-8.

28. Llewellyn AC, Jones CL, Napier BA, Bina JE, Weiss DS. Macrophage replication screen indentifies a novel Francisella hydroperoxide resistance protein involved in virulence. Plos One 2011;6:e24201.

29. Pohanka $M$, Pavlis $O$. Neostigmine modulates tularemia progression in BALB/c mice. Afr J Pharm Pharmacol 2012;6:1317-22.
30. Pohanka M, Sobotka J, Stetina R. Sulfur mustard induced oxidative stress and its alteration by epigallocatechin gallate. Toxicol Lett 2011;201:105-9.

31. Pohanka M, Sobotka J, Jilkova M, Stetina R. Oxidative stress after sulfur mustard intoxication and its reduction by melatonin: efficacy of antioxidant therapy during serious intoxication. Drug Chem Toxicol 2011;34(1):85-91.

32. Pohanka M, Sobotka J, Svobodova H, Stetina R. Investigation of oxidative stress in blood, brain, kidney and liver after oxime antidote $\mathrm{HI}-6$ application in a mouse experimental model. Drug Chem Toxicol 2011;34(3):255-60.

33. Andersson H, Hartmanova B, Ryden P, Noppa L, Naslund L, Sjostedt A. A microarray analysis of the murine macrophage response to infection with Francisella tularensis LVS. J Med Microbiol 2006;55:102333.

34. Alkhuder K, Meibom KL, Dubail I, Dupuis M, Charbit A. Glutathione provides a source of cysteine essential for intracellular multiplication of Francisella tularensis. PLoS Pathog 2009;5:e1000284.

35. Gibson SA, Korade Z, Shelton RC. Oxidative stress and glutathione response in tissue cultures from persons with major depression. J Psychiatr Res 2012:46:1326-32.

36. Svetlanov A, Puri N, Mena P, Koller A, Karzai AW. Francisella tularensis tmRNA system mutants are vulnerable to stress, avirulent in mice, and provide effective immune protection. Mol Microbiol 2012;85:122-41.

37. Novosad J, Holicka M, Novosadova M, Krejsek J, Krcmova I. Rapid onset of ICAM-1 expression is a marker of effective macrophages activation during infection of Francisella tularensis LVS in vitro. Folia Microbiol (Praha) 2011;56:149-54.

38. Chu P, Rodriguez AZ, Arulanandam BP, Klose KE. Tryptophan prototrophy contributes to Francisella tularensis evasion of gamma interferon-mediated host defense. Infect Immun 2011;79:2356-61.

39. Mokgobu Ml, Anderson R, Steel HC, Cholo MC, Tintinger GR, Theron AJ. Manganese promotes increased formation of hydrogen peroxide by activated human macrophages and neutrophils in vitro. Inhal Toxicol 2012;24:634-44.

40. Pohanka M, Pavlis O, Ruttkay-Nedecky B, Sochor J, Sobotka J, Pikula J, Adam V, Kizek R. Tularemia progression accompanied with oxidative stress and antioxidant alteration in spleen and liver of BALB/c mice. J Microbiol 2012;50:401-8.

41. Koc S, Sogut E, Duygu F, Gurbuzler L, Eyibilen A, Aladag I. Evaluation of oxidative stress in patients with tularemia. Afr J Microbiol Res 2012;6:5121-5. 